\title{
Taming A Phoenix: The Year-and-a-Day Rule in Federal Prosecutions for Murder
}

\author{
Donald E. Walther $\dagger$
}

"[N]o person should be adjudged, "by any act whatever, to kill another, who does not die by it within a year and a day thereafter. ...'" In 1894, the United States Supreme Court stated that "such is the rule in this country in prosecutions for murder, except in jurisdictions where it may be otherwise prescribed by statute."2 Since this formulation, neither the Supreme Court nor any other federal court has had occasion to apply the year-and-a-day rule in a federal prosecution for murder. Nevertheless, this Comment suggests that the rule remains a viable doctrine in contemporary federal jurisprudence and that courts should not overlook the rule in federal murder prosecutions.

Section I of this Comment places the year-and-a-day rule in historical context by tracing it from thirteenth-century England to its arrival in the United States. Section II tracks the rule's early evolution in the United States. It concludes that the rule is best understood as a conclusive presumption and that the rule remains good law in federal jurisdictions. Section III suggests that cases involving the intentional infliction of the human immunodeficiency virus (HIV) will bring the year-and-a-day rule to center stage for the first time in more than a century and concludes that in the age of modern medicine the rule should survive only as a rebuttable presumption.

\section{History OF the RULE}

This Section considers how the curious evolution of the yearand-a-day rule, from a statute of limitations in England to a substantive principle on this continent, casts light on the difficulties encountered by American federal courts adopting the rule. Those courts, when confronted with the complex (and often perplexing)

$\dagger$ A.B. 1990, Duke University; J.D. and M.B.A. candidate 1994, The University of Chicago.

${ }^{1}$ Louisville, Evansville \& St. Louis Railroad Co. v Clarke, 152 US 230, 239 (1894).

${ }^{2}$ Id. 
evolution of the rule, chose a flexible construction of the doctrine. This construction provides the key to the rule's persistence in the twentieth century.

\section{A. The Appeal of Murder}

The first mention of a year-and-a-day ${ }^{3}$ rule came in the English Statute of Gloucester in 1278:

It is provided also, that no Appeal shall be abated so soon as they have been heretofore; but if the Appellor declare the deed was done and with that Weapon he was slain, the Appeal shall stand in effect and shall not be abated for Default of fresh Suit, if the Party shall sue within the Year and the Day after the Deed was done. ${ }^{4}$

Because the statute refers to the timing of the suit (as opposed to the time of death), it makes clear that the reference to a year and a day was originally intended as a statute of limitations governing the time in which an individual might initiate a private appeal for murder..$^{5}$

\section{B. The Transformation of the Rule}

As the appeal by the private individual was gradually replaced by the indictment, jurisdiction over the more serious criminal matters was drawn to the king. ${ }^{6}$ The private appeal was eventually

${ }^{3}$ Sir Edward Coke offers an explanation of the extra day: "regularly the law maketh no fraction of a day: and the day was added, that there might be a whole year at least after the stroke, or poyson, etc . . . ." Edward Coke, 3 Institutes 53 (Brooke, 2d ed 1809). See also Courtney S. Kenny, Outline of Criminal Law 135 (Cambridge, 19th ed 1966) (noting that the extra day was added "merely to indicate that the 365 th day after that of the injury must be included" in compliance with an obsolete rule of criminal law that "in reckoning a period 'from' the doing of any act, the period was (in favour of prisoners) to be taken as beginning on the very day when this act was done").

- Statute of Gloucester, $6 \mathrm{Edw}$ 1, c 9 (1278), codified at I Statutes at Large: From the Magna Charta to the 14th Year of K. Edward III (inclusive) 124-25 (Danby Pickering, 1761). See generally, Note, The Abolition of the Year and A Day Rule: Commonwealth v. Ladd, 65 Dickinson L Rev 166 (1961).

S The implications of the rule were unclear even at the outset, with disagreement over whether the time should run from the blow or the death of the victim. In Heydon's Case, 4 Coke's Reports 41, 76 Eng Rep 631 (1558), the court ruled that the statute would not run until the death of the victim. Note, 65 Dickinson $L$ Rev at 167.

- William Holdsworth, 2 A History of English Law 256 (Little, Brown, 4th ed 1936). 
abolished by statute in 1819.7 However, the "year-and-a-day" maxim, having permeated the concept of murder, survived. ${ }^{8}$

The breadth of commentary directed at the rule (most coming after its statutory demise) firmly established a rule which, "by transition, and probably through ignorance," became widely accepted in criminal jurisprudence. ${ }^{10}$ Several authors have attempted to explain the rule's curious transition from a statute of limitations to a substantive principle. One modern court theorized that the rule was "intended to soften the old brutal law regarding homicides." 11 Others have suggested that "[t]he common law rule is one of expediency, probably formulated because of medical difficulties encountered in proving cause of death when a considerable lapse of time intervened between an act or omission, and final cessation of life."12 Bringing with it this checkered history, the revised version of the year-and-a-day rule found a welcome reception across the Atlantic.

59 George III 151 ch 46 (1819).

- For the argument that the rule had gained a foothold independent of the Appeal as early as 1301, see D.E.C. Yale, A Year and a Day in Homicide, 48 Camb L J 202, 203-06 (1989). The author concludes that the rule owes more to its pronouncement by judges as a rule governing the actionability of the felony of murder than it owes to the Statute of Gloucester. Id at 206. In support of this proposition, the author cites the fact that by the statute, the year and a day ran from the death of the victim whereas under the rule in homicide cases, the period runs from the moment of the injury. Id.

- Note, Homicide: Why Death in a Year and a Day?, 19 Chi Kent L Rev 181, 183 (1941).

10 William Hawkins, 1 Pleas of the Crown 79 (Professional Books, 1980) ("[N]o person shall be adjudged by any act whatever to kill another who doth not die thereof within a year and a day after ....."); Joseph Chitty, 3 Criminal Law at 726 (Merriam, 2d ed 1826) (“And in no case can a man be adjudged guilty of homicide, unless the death takes place within a year and a day after the injury to which it is ascribed ...."); James F. Stephen, 3 A History of the Criminal Law of England 8 (MacMillan, 1883) ("No one is criminally responsible for a death which occurs upwards of a year and a day ... after the act by which it was caused.").

${ }^{11}$ Commonwealth $v$ Lewis, 409 NE2d 771, 773 (Mass 1980).

12 William L. Clark and William L. Marshall, Law of Crimes $\$ 10.00$ at 602 (Callaghan, 7th ed 1967). See also Coke, 3 Institutes at 52 (cited in note 3). The difficulties encountered in proving causation were only exacerbated by the fact that juries in criminal trials were not given the benefit of hearing from expert witnesses on the issue. Lewis, $409 \mathrm{NE} 2 \mathrm{~d}$ at 773. But see Note, 19 Chi Kent L Rev at 184 (suggesting that if evidentiary problems were the besis for the rule there should have been a civil counterpart to the rule, and arguing that medicine was capable of discriminating between probable and actual cause of death as far back as the rule's inception in the thirteenth century). 
C. Crossing the Atlantic

The year-and-a-day rule was first applied by a United States federal court in 1891. In Ball $v$ United States, ${ }^{13}$ the Supreme Court overturned the murder convictions of three men when it found that the indictment was fatally deficient in failing to allege that the death of the victim had come within a year and a day from the assault. A proper indictment was later returned and the defendants were convicted.

The Court's language in Ball reveals a subtle tension. At first, the Court notes that " $[b]$ y the common law, both time and place were required to be alleged [in the indictment]. It was necessary that it should appear that the death transpired within a year and a day after the stroke ...."14 While it would seem that the Court was merely referring to a question of procedure, the opinion goes on to note that " $[\mathrm{t}]$ he controlling element which distinguished the guilt of the assailant from a common assault was the death within a year and a day, and also within the same jurisdiction."15 The "controlling element" language implies that the rule was not merely a procedural principle, but displayed substantive qualities as well.

Three years after Ball, the Supreme Court revisited the yearand-a-day rule in Louisville, Evansville \& St. Louis Railroad Co. $v$ Clarke, and held that while "such is the rule in this country," it did not apply to suits for wrongful death. ${ }^{16}$ Construing the applicable Indiana statute for wrongful death actions, the Court paused to consider the railroad's argument that the action should be barred as the deceased did not perish until after a year and a day from the date of injury. As a preface to a discussion of the rule's origin, the Court stated the rationale for the rule as follows: "if the person alleged to have been murdered die after that time, it cannot be discerned, as the law presumes, whether he died of the stroke or poison, etc., or a natural death; and, in case of life, a rule of law ought to be certain."17

${ }^{23} 140$ US 118 (1891).

14 Id at 133.

15 Id.

18152 US 230, 239 (1894). The appellee's testator had died from injuries incurred as a result of the negligence of the appellant railroad company. Id at 234-35.

${ }_{17}$ Id at 239, citing Coke, 3 Institutes 53 (cited in note 3 ). One commentator has suggested that the Court's refusal to recognize the rule in a civil wrongful death action is at odds with the Court's justification for the rule. See Note, 19 Chi Kent L Rev at 184 (cited in note 9). If the Court was genuinely concerned about the state of medicine and the inadequacies of forensic pathology, why apply the rule only in criminal trials? The Clarke court itself 
The most remarkable aspect of the Clarke opinion, in light of Ball, is the Court's analysis of the rule's heritage and conclusion that it constituted a rule of evidence. The Court, relying on the learned commentary of Hawkins, Blackstone, and Coke, asserted that the rule at common law was "undoubtedly" that the victim must die within a year and a day before a charge of murder might be levied. The Court found (citing no authority) that "[i]n prosecutions for murder the rule was one simply of criminal evidence"18 and stated that "such is the rule in this country in prosecutions for murder, except in jurisdictions where it may be otherwise prescribed by statute."19 The Court's statement thus enlivens the debate over the proper characterization of the rule when compared with the Ball Court's apparent understanding of the rule as a substantive element distinguishing murder from common assault.

The history of the year-and-a-day rule is therefore remarkable, if only for its incongruity. Faced with the rule's seemingly inexplicable survival following the demise of the appeal, the Supreme Court in Clarke chose to declare broadly that the rule was one merely of criminal evidence. How could the Court make reference to the rule as a controlling element of homicide on one hand and as a principle of criminal evidence on the other? This critical distinction provides the framework for the following discussion of the rule's contemporary viability.

\section{Survival of the Rule Today: A Descriptive Analysis}

In an effort to determine whether the year-and-a-day rule was ever explicitly overruled in federal jurisdictions, Part A of this Section focuses on federal cases in which the rule has been mentioned and concludes that no federal court has expressly abrogated the rule. Part B solves the apparent paradox of Section I by categorizing the rule as a conclusive presumption that displays both substantive (Ball) and evidentiary (Clarke) facets. Part B concludes by rejecting the possibility that the rule was implicitly abrogated by either the federal murder statute or the Federal Rules of Evidence.

had provided the answer: "The reasons upon which the rule of a year and a day were applied ... do not apply with the same force in purely civil proceedings that involve no element of punishment, but only provide compensation to certain relatives of the decedent ...."152 US at 242. In the Court's view, it was the gravity of a death penalty that warranted deference to an artificial standard as a safeguard when determining causation-a consideration altogether absent in a civil suit for damages.

18 Id at 241 (emphasis added).

10 Id at 239. 
A. Expressly Overruled?

Although a majority of states have accepted the Supreme Court's invitation to decide the matter of the year-and-a-day rule for themselves, ${ }^{20}$ no federal court has ever impugned its validity. To the contrary, the cases indicate acknowledgment of the rule as recently as 1979 .

1. Supreme Court decisions.

Following the Court's endorsement of the year-and-a-day rule in its 1894 decision in Clarke, the Court remained silent on the rule until 1932. In Hagner $v$ United States ${ }^{21}$ the Court considered the sufficiency of an indictment for murder. Citing the Ball rule with approval in dictum, Justice Sutherland noted that "to constitute murder it is necessary that death shall occur within a year and a day from the time of the fatal stroke."22 The Court apparently regarded the rule as something more than an antiquated premise.

The Supreme Court next mentioned the rule in 1973. Again citing Ball with approval, the Court in Illinois v Summerville recited the facts and holding in Ball. ${ }^{23}$ Lending little insight into the Court's position on the rule, the statement is noteworthy only in that it represents the last occasion on which the Court mentioned the rule.

\section{Other federal decisions.}

The first federal court other than the Supreme Court to make reference to the year-and-a-day rule with respect to federal law did

${ }^{20}$ A discussion of the year-and-a-day rule in state jurisdictions falls outside the scope of this Comment. For a general discussion of state approaches, see Annotation, Homicide as Affected by Lapse of Time Between Injury and Death, 60 AlR3d 1323 (finding that 27 states have maintained the rule, 8 states have abrogated or modified it, and 1 state has found that the legislature abolished the rule when it passed the criminal code and omitted any mention of it). Note that those jurisdictions that have patterned their criminal statutory scheme after the American Law Institute's Model Penal Code have rejected the rule. See American Law Institute, Model Penal Code and Commentaries $\$ 210.1$ at 9 (1962) (this section "renders unnecessary the ancient requirement that death of another take place within a year and a day of the actor's conduct"). For a list of those states, see 10 Uniform Laws Annotated 2 (West, Supp 1991) (indicating that New Jersey 2C NJ Stat Ann 1-1 et seq (West 1979), and Pennsylvania, 18 PA Cons Stat Ann $\S 101$ et seq (Purdon 1973) have adopted provisions substantially identical to the MPC).

21285 US 427 (1932).

22 Id at 431 (emphasis added).

${ }^{23} 410$ US 458, 467 (1973). 
so in 1896 in United States $v$ Hewecker. ${ }^{24}$ The U.S. District Court for the Southern District of New York held that a federal statute that failed to specify that death must occur within a year and a day could not be construed as a murder statute.

Eighty-three years later, the Eighth Circuit, in Merrill $v$ United States ${ }^{25}$ indicated that it would be prepared to apply the year-and-a-day rule under appropriate circumstances. ${ }^{26}$ In dicta, the court noted:

Although the present case involves a killing during a bank robbery rather than a murder, the Ball rules would appear applicable. In particular, the time of death would be equally important in a case such as this as in a murder case, for the year-and-a-day rule would apply with equal force. ${ }^{27}$

The court went on to note, however, that the issue had been waived because, absent exceptional circumstances, the sufficiency of an indictment was not open to collateral attack following conviction. ${ }^{28}$ The Merrill opinion represents both the first and last time a court of appeals has acknowledged the rule.

Thus, neither the Supreme Court nor any other federal court has ever rejected the year-and-a-day rule. In fact, the dicta of those cases that mention the rule actually suggest that it is just as valid today as when it was adopted by the Hewecker court late in the nineteenth century. Yet before accepting that conclusion, one must consider the pitfalls that await a common law precept in the age of statutes and federal rules.

\section{B. Implicitly Overruled?}

The following discussion considers the possibility that the year-and-a-day rule has been implicitly overruled by Congress. This Part employs the framework suggested by the Supreme Court's conflicting descriptions of the rule both as a controlling element of homicide and a rule of criminal evidence. ${ }^{29}$ The rule is

3479 F 59 (S D NY 1896).

${ }^{28} 599$ F2d 240 (8th Cir 1979).

${ }^{26}$ See also Meyer v United States, 424 F2d 1181, 1190 (8th Cir 1970).

27599 F2d at 242.

28 Id.

29 Admittedly, the distinction between the rule as a substantive principle and as an evidentiary matter seems empty for practical purposes. Under either classification, the rule would preclude indictment when the death of the victim came more than a year and a day after the blow. The difference remains significant only for purposes of determining the rule's continued viability as opposed to its applicability. 
first defined as a conclusive presumption that demonstrates both of these qualities in an effort to reconcile the Court's statements. Attention next turns to the federal murder statute in an effort to determine whether the rule was repealed when the drafters of the statute failed to incorporate it. The legislative history of the Uniform Code of Military Justice provides an analogue, which suggests that the rule survived enactment of the federal murder statute. This Part concludes by rejecting the possibility that the rule was superseded by the Federal Rules of Evidence, which generally admit all relevant evidence. Although the Federal Rules generally override contrary judicial doctrine, the apparent conflict with the year-and-a-day rule is illusory given the substantive characteristics of the rule as a conclusive presumption.

1. An introduction to the rule as a conclusive presumption.

Before one can hope to assess the current viability of the yearand-a-day rule in contemporary federal jurisprudence, one must first reconcile the Supreme Court's statements in Ball and Clarke concerning the nature of the rule. This Section argues that the Court's statements, though distinguishable, are facets of the same gem. In short, a rule of evidence (Clarke) that operates to exclude relevant information in every case where the murder victim dies more than a year and a day from the blow is termed a conclusive presumption. Conclusive presumptions are, in turn, best understood as substantive principles of law (Ball).

In order fully to understand the Court's conception of the year-and-a-day rule in Clarke, it is useful to gain a contextual understanding of the Supreme Court's statement that "[i]n prosecutions for murder the rule was one simply of criminal evidence."30 Eleven years before Clarke, the Supreme Court decided Kring $v$ Missouri, ${ }^{31}$ in which it held that the defendant, convicted of homicide, should not be tried under a law not in force at the time of the crime, as it violated the ex post facto clause of the Constitution. The Court paused to define a rule of evidence, stating that the phrase "signifies those rules of law whereby we determine what testimony is to be admitted and what rejected in each case, and what is the weight to be given to the testimony admitted." 32

\footnotetext{
30 See text accompanying note 19.

31107 US 221 (1883).

32 Id at 232.
} 
The Court was therefore correct to term the year-and-a-day rule a rule of evidence to the extent that the rule operates to determine what evidence is rejected when the victim dies more than a year and a day from the time of the injury. Yet in no case will the rule operate to determine "the weight to be given to the testimony admitted" since once triggered, the rule terminates the proceeding altogether. Given this finality, it is proper to call this rule of evidence a "conclusive presumption."

The English first dubbed the year-and-a-day rule a conclusive presumption. Halsbury, in his Laws of England, stated: "If death does not ensue until after the expiration of a year and a day from the day when the injury was inflicted, it is an irrebuttable presumption of law that the death is attributable to some other cause ....".33

While the Supreme Court failed to use Halsbury's precise terminology when adopting the rule, the Court's opinion in Ball suggests that the rule is properly understood as a conclusive presumption in this country as well. The Ball Court emphasized that "the controlling element which distinguished the guilt of the assailant from a common assault was the death within a year and a day." 34 Wigmore helps reconcile Ball's treatment of the rule as substantive with the English notion of a conclusive presumption:

Wherever from one fact another is said to be conclusively presumed, in the sense that the opponent is absolutely precluded from showing by any evidence that the second fact does not exist, the rule is really providing that where the first fact is shown to exist, the second fact's existence is wholly immaterial ... and to provide this is to make a rule of substantive law .... . 35

Thus, the year-and-a-day rule is best understood as a conclusive presumption. Such an understanding gives life to the proposition that the rule is one of "criminal evidence" (Clarke) while comporting with the notion that the rule has substantive bite (Ball).

2. The federal murder statute does not reject the rule by negative implication.

The current federal murder statute, 18 USC § 1111, states:

s3 H.S.G. Halsbury, 9 Laws of England $\S 1157$ at 571 (Butterworth, 1909).

34140 US at 133.

3s John H. Wigmore, 9 Evidence $\$ 2492$ at 307-08 (Little, Brown, 1981) (emphasis added); see also Edward Cleary, McCormick on Evidence $\$ 342$ at 966 (West, 3d ed 1984). 
Murder is the unlawful killing of a human being with malice aforethought. Every murder perpetrated by poison, lying in wait or any other kind of willful, deliberate, malicious, and premeditated killing . . . is murder in the first degree. Any other murder is murder in the second degree. ${ }^{36}$

One might expect the year-and-a-day rule to appear in the federal murder statute if conclusive presumptions are truly rules of substantive law. ${ }^{37}$ Yet not all conclusive presumptions are to be so strictly construed; $;^{38}$ nor do they necessarily qualify as an essential part of the definition of the crime to which they adhere. There are two strong arguments that this conclusive presumption survived despite the fact that it was omitted from the statute.

First, the framers of the original murder statute (which also omitted the year-and-a-day rule) ${ }^{39}$ not only knew about the rule, ${ }^{40}$ but drafted the statute against a background norm that operated to insulate the rule from all but the most explicit abolition. Just two years before Congress undertook to revise and codify the penal laws, Wharton completed the third edition of his treatise on homicide, in which he cited a Texas case as an example of the proposition that "these requirements are not abrogated by statutory provisions as to homicide, where they are not, either directly or

36 Federal jurisdiction under 18 USC \& 1111 (1988) extends to all persons within the special maritime and territorial jurisdiction of the United States, as defined in 18 USC $\S 7$ (1988).

37 Recall Wigmore's statement that to apply a conclusive presumption is "to make a rule of substantive law . ..." See text accompanying note 35 .

ss See Charles A. Wright and Kenneth W. Graham, 21 Federal Practice and Procedure: Evidence $\$ 5129$ at 627 (West, 1977) ("with some exceptions, courts have tended to judge conclusive presumptions as rules of substantive law").

39 The first federal codification of the definition of murder occurred at 35 Stat 1143 (Mar 4, 1909). Prior to these efforts, the statute governing the offense of murder failed to define either "murder" or "homicide." See William McKinney, 3 Federal Statutes Annotated $\S 5339$ at 231 (Thompson 1904). Thus, the drafters clearly viewed their task to be codification of a definition. When introducing the revised code to the Senate, Senator Heyburn noted that "[the murder statute] enlarges the common law definition and is similar in terms to the statutes defining murder in a large majority of the States." Revision of the Penal Laws, Hearings on S 2982 before the Senate as a Whole, 60th Cong, 1st Sess 1184, 1185 (1908).

10 There is good evidence that the drafters were cognizant of the rule. Referring to the precise page of the opinion upon which the Court in Ball made clear its acceptance of the year-and-a-day rule, the drafters took issue not with the rule, but with the requirement that the indictment demonstrate the place of death. Revision and Codification of Laws, S Rep No 60-10 pt 1, 60th Cong, Ist Sess 1, 12 (1908), citing, among other cases, Ball v United States, 140 US at 133-36. 
indirectly, referred to."41 Furthermore, it appears that the Special Joint Committee on the Revision of Laws would have been aware of such authority-especially in light of the fact that the Supreme Court had explicitly referred to Wharton's work in both Ball $\mathbf{4}^{\mathbf{2}}$ and Clarke $^{43}$ when discussing the implications of the year-and-a-day rule.

Second, there is explicit evidence that the rule will indeed persevere until expressly abolished. In another federal context, military law, the year-and-a-day rule survived despite its omission from the relevant statute, until it was expressly considered and rejected. The legislative history of the Uniform Code of Military Justice demonstrates that although the rule was originally omitted from the military murder statute, it remained a viable doctrine in military law until explicitly rejected. Ten years after amending the federal murder statute (again without reference to the rule), Congress enacted the Uniform Code of Military Justice (UCMJ) in 1950.44 Despite the fact that the murder statute did not mention the year-and-a-day rule, the Committee charged with drafting the UCMJ felt it necessary to note explicitly its intention to omit the rule:

It is intended that the common law "year-and-a-day" rule shall not be applicable. In early times, when the rule originated, it was difficult to ascertain the true cause of death if a substantial period of time intervened. With modern developments in medical science the only justification for this rule no longer exists. ${ }^{45}$

\footnotetext{
41 Francis Wharton, The Law of Homicide $\S 18$ at 19 (Lawyer's Co-op, 3d ed 1907). For support on this point, Wharton cites Hardin v State, 4 Tex App 355 (1878). The court in that case, having noted that the state legislature had passed laws concerning both the crime of homicide and the sufficiency of an indictment, went on to find: "Notwithstanding these provisions of our criminal law, it is undeniably true that they have not altered or in anywise changed the fundamental rule of the common law that, to make the offense of murder in the first degree, it is necessary to allege, and necessary to prove, the death, and that the deceased literally died within a year and a day after he received the injury of the wounds which occasioned the death." Id at 370.

12140 US at 134.

is 152 US at 239.

“ Edward M. Byrne, Military Law \& 110 at 9 (Naval Institute Press, 3rd ed 1970).

1s Uniform Code of Military Justice, Text, References and Commentary Based on the Report of the Committee on a Uniform Code of Military Justice to the Secretary of Defense 144 (1950) (Morgan draft).
} 
The Committee felt the need to reject the rule affirmatively in large part because the Manual for Courts-Martial ${ }^{48}$ had noted that a conviction for murder required that "death resulted from an injury received by [defendant], that such injury resulted from an act of the accused, and that the death occurred within a year and a day of such act." ${ }^{17}$ This is remarkable in that the Articles of War, ${ }^{48}$ establishing murder as a punishable offense in the military, had never specifically mentioned the rule. Following enactment of the UCMJ in 1950, the Manual for Courts-Martial omitted the requirement that death occur within a year and a day and provided simply that death must result "from the act or omission of the accused." 49 Thus, the rule survived omission from the Articles of War until it was expressly rejected.

3. The rule survived the enactment of the Federal Rules of Evidence.

If the year-and-a-day rule functions in some respects as a rule of evidence, ${ }^{50}$ one might argue that the rule was superseded by the Federal Rules of Evidence. This Section considers and rejects this argument, concluding that the conflict between the Federal Rules and the year-and-a-day rule is largely illusory.

By order of the Supreme Court in 1972, a body of evidentiary rules was transmitted to Congress for approval. The legislature eventually adopted the Federal Rules of Evidence in 1975. Federal Rule of Evidence 402 explicitly states that all relevant evidence is admissible, "except as otherwise provided by the Constitution of the United States, by Act of Congress, by these rules, or by other

\footnotetext{
48 The manual, promulgated by the President under the authority of 10 USC $\S 836$ (1988), governs pre-trial, trial, and post-trial procedures in military courts.

${ }^{47}$ United States v Craig, 10 CMR 148, 155 (1953), quoting Manual for Courts-Martial, U.S. Army 231 paragraph $179 \mathrm{a}$ (1949).

48 4I Stat 787-812 (as amended), codified at 10 USC $\$$ 1471-1593 (1946) (as amended by Pub L 759, 80th Cong, 2d Sess (1948) (repealed)). Article of War 92: "Any person subject to military law found guilty of murder shall suffer death or imprisonment for life, as a courtmartial may direct; but if found guilty of murder not premeditated, he shall be punished as a court-martial may direct."

49 Manual for Courts-Martial, United States, IV-7 paragraph 43 (1984).

so See Section IIB(1). For cases holding that the year-and-a-day rule is purely a rule of evidence, see Commonwealth v Ladd, 166 A2d 501, 504 ( $\mathrm{Pa}$ 1960) (citing Clarke and concluding the rule is "only a rule of evidence or procedure"); People $v$ Snipe, 102 Cal Rptr 6, 8 (Cal App 1972) (noting that when the rule was incorporated into the Criminal Practice Act, it was made a rule of evidence); Head v State, $24 \mathrm{SE} 2 \mathrm{~d} 145$ (Ga App 1943); Jones v Dugger, 518 SE2d 295, 298 (Fla App 1987); Elliott v Mills, 335 P2d 1104, 1111 (Okla Crim App 1959); State v Huff, 11 Nev 17, 20-21 (1876).
} 
rules prescribed by the Supreme Court pursuant to statutory authority." "11

The apparent conflict with the year-and-a-day rule hinges on the fact that the rule technically bars the admission of otherwise relevant inculpatory evidence (under Rule 402) in the event the victim dies more than a year and a day after receiving the fatal blow. By barring indictment of the assailant, the rule would effectively render such evidence inadmissible by denying the prosecution any opportunity to demonstrate causation even in the event that the issue of culpability was undisputed (for example, where a confession had been obtained).

To the extent that a common law rule is inconsistent with a particular Federal Rule of Evidence, "the Rule prevails." however appealing it may first seem, the argument that the yearand-a-day rule has been superseded by the Federal Rules of Evidence must fail. First, the Federal Rules of Evidence cannot trump a substantive principle. To hold the Supreme Court in Clarke to a strict definition of "evidence" ignores both the subtleties of that decision and the substantive nature of the conclusive presumption. As such a presumption, the year-and-a-day rule must be understood as a substantive element of the crime of murder in federal jurisdictions. The Federal Rules could no more abolish this rule than could they remove any other element of the crime of murder in federal jurisdictions. Second, "[i]t is clear that in enacting the Federal Rules of Evidence Congress did not intend to wipe out the years of common law development in the field of evidence; indeed the contrary is true. The new rules contain many gaps and omissions and in order to answer these unresolved questions courts certainly should rely on common law precedent." Rules of Evidence nowhere mention the year-and-a-day rule and to infer that the rule is nonetheless implicitly abolished is to ignore the lessons of the UCMJ.

No federal court has ever rejected the year-and-a-day rule. The more intriguing question has been whether or not the federal homicide statute or the Federal Rules of Evidence estranged the rule from federal jurisprudence. Neither wholly substantive nor purely evidentiary in the technical sense of that word, the rule is properly understood as a conclusive presumption which survived both omission from the murder statute and the Federal Rules.

ot FRE 402 (West, 1990).

${ }^{82}$ Bourjaily v United States, 483 US 171, 178-79 (1987).

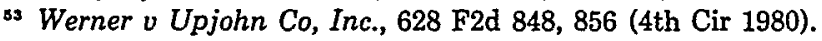




\section{Survival of the Rule Today: A Modern Forum and a Normative ANALYsis}

Section II concludes that the year-and-a-day rule remains a viable doctrine in twentieth-century jurisprudence. But should the rule survive? To place the question in its modern context, this Section first presents a plausible forum in which federal courts will be forced to confront the rule for the first time in over a century: cases involving the intentional infliction of HIV, in which victims typically die beyond a year and a day from acquired immunodeficiency syndrome (AIDS). This Section then argues that the rationale behind the rule is no longer persuasive given the enhanced probability of correctly determining the cause of death in the age of modern medicine, and that the rule in its present form is consequently untenable. Following a discussion of several counter-arguments in favor of the rule, the Section concludes that there remains a place in modern homicide law for the rule as a rebuttable presumption.

\section{A. The Year-and-a-Day Rule and AIDS-An Introduction}

Although applicable to all latent death cases, the year-and-aday rule is most troublesome in AIDS-related cases involving intentional infliction of HIV. ${ }^{54}$ Even in the event that prosecutors can demonstrate causation beyond question shortly after transmission, the year-and-a-day rule would typically bar indictment of the individual who intentionally transfers HIV provided that the victim dies more than a year and a day after infection..$^{55}$

1. A new forum for the rule.

According to the Public Health Service, roughly 840 HIV-related cases were filed in civil and criminal courts across the country as of September $1,1991 .^{56}$ If the year-and-a-day rule is to emerge in these cases, it will enter at the stage when prosecutors

st Infection is caused by the transfer of HIV, which later causes AIDS.

ss This is the rule rather than the exception in AIDS cases. See Alan Lifson, History of HIV Infection, San Francisco Chronicle A2 (Dec 27, 1989) (noting that the risk of developing AIDS after HIV infection within a year is $0 \%$, only $4 \%$ after three years, but $54 \%$ after ten years). Once an individual contracts the AIDS virus, his lifespan is, on average, two years. See Joanne Wojcik, Leadership Role Urged for Business on AIDS Education, Business Insurance 17 (Apr 6, 1992) ("Two out of three people with AIDS die within 2.1 years of infection.").

${ }^{66}$ Rorie Sherman, Criminal Prosecutions on AIDS Growing, The National Law Journal 3 (Oct 14, 1991). 
charge an individual for murder upon the death of the victim from AIDS. Yet prosecutors in intentional HIV-infliction cases have traditionally met with little success when trying to bring even attempted murder charges in such cases. Two cases illustrate the typical stumbling blocks.

The first problem is the difficulty of proving specific intent to kill. In 1987, Joseph Markowski, a twenty-nine year old Los Angeles resident, was charged with attempted murder for selling his blood and engaging in prostitution while conscious of his HIV infection. ${ }^{57}$ The District Attorney cited the "egregiousness" of Markowski's conduct to justify the charge. ${ }^{58}$ However, the judge dismissed the charges because there was no evidence of a specific intent to kill. ${ }^{\text {so }}$

The second stumbling block in HIV-infliction cases is the diffculty of demonstrating causation. For example, the lack of documented studies showing that the virus could be transmitted through saliva was cited for the dismissal of charges against a defendant in Flint, Michigan. The defendant had been charged with attempted murder after spitting on two police officers. ${ }^{60}$

Though the above examples concern attempted homicide prosecutions, the difficulties involved in proving intent and causation surely figure prominently as reasons for the scarcity of homicide prosecutions as well. But these cases are getting easier to prove. While modern technology has little to offer the prosecutor when proving intent, recent advances provide the prosecutor with powerful tools for proving causation.

Traditionally, "[c]ontact tracing among high-risk groups [was] difficult in areas with a high reservoir of infection because it [led] the investigator to virtually every member of the group . . .." Modern genetic tracing techniques have made identification of the specific carrier much easier. ${ }^{62}$ As these techniques improve and the

${ }^{57}$ Richard Lacayo, Assault with a Deadly Virus; What Should Courts Do When AIDS is Allegedly Used as a Weapon?, Time 63 (Jul 20, 1987).

ss Id.

so See Martha A. Field, Have Sex, Go to Jail; AIDS and the Law, Playboy 34 (August 1988).

${ }^{80}$ Robert Boorstine, Criminal and Civil Litigation on Spread of AIDS Appears, New York Times Al (Jun 19, 1987).

${ }^{61}$ Larry O. Gostin, Public Health Strategies for Confronting AIDS, $261 \mathrm{~J}$ Amer Med Assoc 1621, 1626 (Mar 17, 1989).

${ }_{82}$ Possible Transmission of Human Immunodeficiency Virus to a Patient During an Invasive Dental Procedure, 126 AMA Archives of Dermatology 1553 (1990) (noting that while DNA sequencing of HIV strains can be used to demonstrate a similarity between two 
frequency of such cases increases, ${ }^{63}$ we can expect that prosecutors will not only bring homicide charges upon the death of the victim, but will succeed in winning convictions-unless the year-and-a-day rule intervenes.

Several commentators have noted that the year-and-a-day rule may prove to be a substantial roadblock to successful prosecution of these cases. ${ }^{64}$ Addressing the Canadian Bar Association at a conference in London in 1990, a criminal lawyer opined that the yearand-a-day rule would pose significant difficulties for the prosecutor trying these cases in England..$^{65}$ In the United States, one writer viewed Florida's decision to abolish the rule ${ }^{6 B}$ as one of the littlediscussed yet "potentially most far-reaching" criminal reforms affecting AIDS prosecutions in the state. ${ }^{67}$ Though the legislative history of the Florida statute repealing the rule reveals no conscious understanding of the implications for AIDS cases, another writer acknowledged that "the abolition of the rule makes it easier for people infected with HIV to be prosecuted for homicides or attempted homicides."

2. An illustration of the rule's impact.

United States $v$ Kazenbach ${ }^{69}$ provides a convenient framework for the discussion of intentional HIV infliction in a federal forum. David Kazenbach was an inmate suffering from AIDS at the Medical Center for Federal Prisoners in Springfield, Missouri. $\mathrm{He}$ allegedly bit, scratched, and spat at correctional officers while they attempted to remove him from his cell in the special lockdown unit in the facility. ${ }^{70}$ Kazenbach was convicted in 1986 on

individuals, the process is new and the scarcity of data pertaining to other epidemiologically related patients must be considered).

83 There are currently twelve million HIV-infected individuals worldwide and that number is expected to rise as high as forty million within the next eight years. Larry Kramer, Who Says AIDS is Hard to Get?, Newsweek 12 (Apr 13, 1992). With such an increase in the number of infected individuals, one would expect a commensurate rise in HIVrelated crimes.

64 See, for example, Field, Playboy at 34 (cited in note 59) ("[C]harging people who sexually transmit AIDS with homicide ... requires that the victim has died and, in many states, that the victim died within a year and a day of the act that caused death. It can take much longer than a year for a person to die of AIDS.").

${ }^{65}$ Frances Gibb, Law Not Suitable for AIDS Crime, The Times (London) (Sep 26, 1990).

${ }^{B 8}$ Fla Stat $\$ 782.035$ (Supp 1992).

${ }^{67}$ Note, Florida's Omnibus AIDS Act of 1988, 16 Fla St U L Rev 441, 512 (1988).

${ }^{88}$ Id.

${ }^{60} 824$ F2d 649 (8th Cir 1987).

${ }^{70}$ Id at 650 . 
three counts of assaulting a correctional officer in violation of 18 USC $\S 111$ and $\S 1114 . .^{71}$ The Eighth Circuit found sufficient evidence for the jury to convict and the requisite intent for assault. ${ }^{72}$

One can only speculate that the federal prosecutor, when confronted with the problems of proving intent and causation in order to gain an attempted murder conviction, chose to pursue assault charges instead. If Kazenbach had occurred today however, the prosecutor would most certainly feel more comfortable proving causation. If the officers went on to contract AIDS and died several years later, the prosecutor could now rely on the genetic tracing techniques to bring murder charges against Kazenbach. ${ }^{73}$ Yet, in light of Merrill $v$ United States, ${ }^{74}$ in which the Eighth Circuit acknowledged the continuing vitality of the year-and-a-day rule, there is a strong indication that the court would dismiss the indictment. Though the court ultimately ruled that the parties had waived the issue through failure to raise it prior to trial, it seems clear that the court would be willing to apply the year-and-a-day rule in the event a defendant asserted it at the correct stage of proceedings..$^{75}$

7118 USC \$ 111 (1988) concerns the assault of federal employees while in the performance of their duties. Those personnel covered by the statute are listed in 18 USC $\$ 1114$ (1988) and include "any officer or employee of any United States penal or correctional institution."

72824 F2d at 652.

${ }^{73}$ See note 62 . Federal jurisdiction under 18 USC $\S 1111$ extends to all persons within the special maritime and territorial jurisdiction of the United States as defined in 18 USC \& 7. Territorial jurisdiction under that statute extends to federal correctional institutions. There would be no statute of limitations violation if the Government brought such a charge since the crime of murder is not complete until the victim dies. See Diaz v United States, 223 US 442,449 (1912) ("The death of the injured person was the principal element of the homicide....").

74599 F2d 240, 242 (8th Cir 1979).

${ }^{75}$ Less than two years later, in United States v Lincoln, 630 F2d 1313 (8th Cir 1980), the Eighth Circuit had occasion to consider the sufficiency of an indictment for homicide under 18 USC $\$ 1111$. The court reprinted the full text of the indictment in its opinion, and noted that it was "clearly sufficient to charge the crime of murder as defined in 18 USC $\S 1111$ (a)...." Id at 1316. Although the indictment stated the date of death, there was no explicit assertion that the deceased had perished within a year and a day from the assault. See id at 1315. The apparent discrepancy is reconciled by Wharton, who states that "where the fact appears in an indictment for homicide that death occurred within a year and a day after the assault which caused it, it is sufficient, and any more particular statement of time will be regarded as an immaterial allegation ...." Wharton, Homicide § 18 at 19-20 (cited in note 41 ). 


\section{B. An Argument for Change: A Rule With No Foundation}

Assuming that federal prosecutors do bring homicide charges for the death of one who was intentionally infected with HIV, they will have to confront the year-and-a-day rule. There is a strong argument that those same technological advances that should spur the prosecutor to bring these charges should spur the Supreme Court $^{76}$ or Congress to abolish the year-and-a-day rule and let these prosecutions go forward. ${ }^{77}$

The Supreme Court wrote in Clarke that "if the person alleged to have been murdered die[s] after that time, it cannot be discerned, as the law presumes, whether he died of the stroke or poison, etc., or a natural death . ..."78 When faced with the finality of capital punishment, the Court eschewed a demonstrably fallible science and conclusively foreclosed any attempt to prove causation after a year and a day had passed.

The Court's fears were well founded. Early in the nineteenth century, modern medicine began to emerge, with new discoveries in the anatomy of tissues pointing to a keener approach to pathol${ }^{\circ}{ }^{7}{ }^{79}$ but progress was slow. When the Supreme Court decided Clarke in 1894, the debate over spontaneous generation had only recently been put to rest by Louis Pasteur ${ }^{80}$ and the weakest point

${ }^{26}$ This Comment assumes, as it must, that federal district courts and appellate courts will recognize the Supreme Court's decisions in Ball and Clarke as precedent that establishes the year-and-a-day rule as good law. Those lower courts will consequently be forced to dismiss the indictment before them in order to present the question to the Court for review.

77 Whether the Supreme Court will be able to abolish the rule retrospectively without violating the ex post facto clause of the Constitution is debatable. Dean Cooley has written that "[t]he defendant in this case could not have so regulated his blows as to ensure that his victim would die a month after the year and a day barrier came into existence, nor should due process afford him a right to try." Thomas M. Cooley II, 1960-61 Survey of Pennsylvania Law, 23 U Pitt L Rev 263, 265 (1961). Yet in the case of the HIV-infected assailant, it would appear that the defendant in the first case before the Court could indeed claim that he or she relied upon the fact that the victim would not die as a result of the virus within a year and a day. It is suggested that the Court will be forced in this instance to apply its decision in Miller $v$ Florida, 482 US 423,430 (1986), which held that a law is ex post facto if 1) it is retrospective in the sense that it applies to events occurring before its enactment, and 2) it disadvantages the offender in that it affects substantial personal rights. Rules that are strictly matters of procedure or evidence do not affect matters of substance, do not affect substantial rights, and are hence outside the scope of the clause. As a conclusive presumption that demonstrates substantive characteristics (see Section IIB(1)), the year-and-aday rule appears to fit within the Miller criteria. The Court would therefore be limited to abolishing (or altering) the rule prospectively.

78 152 US at 239 (emphasis added).

${ }^{79}$ Richard H. Shyrock, The Development of Modern Medicine 149 (Penn, 1936).

so Id at 269. Pasteur's sterilization techniques put an end to the controversy in 1858. 
in medical education in Chicago was pathological anatomy. ${ }^{81}$ The Court remained doubtful that science could provide the answers to difficult issues of causation, and instead chose the comfort of an established principle, reasoning that "in case of life, a rule of law ought to be certain." 82

The science of pathology has predictably evolved over the last hundred years:

From time immemorial society has insisted on a definite designation of cause of death. For centuries this has meant some participation by the medical profession in the determination, which, to be sure, as often as not in the past, has been inadequate and faulty. With increasing precision in understanding, however, and especially through exact studies in pathology, medical pronouncement has gained greatly in accuracy. ${ }^{83}$

Several states have concurred, extolling the virtues of modern medicine and noting that such advances have rendered the yearand-a-day rule an anachronism. ${ }^{84}$

Homicide cases involving the intentional infliction of HIV most clearly illustrate that the year-and-a-day rule has outlived its usefulness as a conclusive presumption in light of the present state of medicine. Since the worldwide epidemic of AIDS was first recognized in $1981,{ }^{85}$ medical researchers have made great strides in diagnosing the disease. The Center for Disease Control's abridged case definition of AIDS included more than twenty precise symptomatic conditions as early as $1987{ }^{88}$ Because modern medicine can clearly distinguish the source of the victim's death, the original ra-

${ }^{81}$ Lester S. King, Medical Education: The Decade of Massive Change, $251 \mathrm{~J}$ Amer Med Assoc 219 (Jan 13, 1984).

2 Clarke, 152 US at 239.

${ }^{83}$ Esmond R. Long, A History of Pathology 184 (Dover, 1965).

s4 See People v Stevenson, 331 NW2d 143, 146 (Mich 1982); Lewis, 409 NE2d at 775; State v Sandridge, 365 NE2d, 898, 899 (Ct. of Common Pleas, Cuyahoga County, Ohio 1977); Ladd, 166 A2d at 507; Elliott, 335 P2d at 1113.

ss Vijay V. Joshi, Pathology of AIDS and Other Manifestations of HIV Infection 7 (Igaku-Shoin, 1990).

${ }^{88}$ Id at 13. 
tionale underlying the year-and-a-day rule ${ }^{87}$ has been rendered obsolete. $^{88}$

\section{A Counter-Argument: The Need for Bright Line Rules}

Even in light of the deteriorating rationale behind the yearand-a-day rule, the rule undoubtedly retains a certain appeal. The legal culture's continued affair with the rule since the thirteenth century derives largely from a preference which those societies have shared: the preference for determinate or "bright-line" rules. There are two compelling components of this preference: the search for efficient justice and the preference for settled claims.

1. Efficiency: balancing the benefits against the costs.

Professor Alschuler, writing on the Fourth Amendment, notes:

A critical issue which appears and reappears in virtually every phase of government is how much to sacrifice justice in an individual case for the sake of administering justice by rules.... [T] he variety and unpredictability of human behavior make extremely difficult the articulation of general principles that will yield justice in almost every situation that they address. When the best rules that our powers can devise produce injustice often enough, we do well to abandon them even at the price of lawlessness. ${ }^{88}$

Justice White has noted that "[b]right-line rules are indeed useful and sometimes necessary. ..." " In determining whether the year-and-a-day rule is one such "necessary" rule, one must consider both the benefits and the costs involved in applying the rule.

One of the primary benefits of the rule is efficiency. By eliminating a case-by-case inquiry, the year-and-a-day rule not only

\footnotetext{
${ }^{87}$ See Clarke, 152 US at 239. One might argue that the continued difficulties involved in ascertaining the culpability of any specific individual evoke the same fears of mistaken identity which the rule was designed to eradicate. This latter matter is not within the realm of the year-and-a-day rule. To analogize, while the rule applies to a determination of whether the bullet killed the victim, the matter of who pulled the trigger has always been (and should continue to be) uniquely within the province of the jury.

ss It is ironic that a defendant can assert the year-and-a-day rule in an age where modern medicine can prolong the life of the gravely injured well beyond that limitation, where if the victim had received the identical injury in the thirteenth century, he would have died before the rule came into play and the defendant would have been convicted. See State $v$ Young, 390 A2d 556, 566 (NJ 1978) (Pashman dissenting).

89 Albert W. Alschuler, Bright Line Fever and the Fourth Amendment, $45 \mathrm{U}$ Pitt L Rev 227 (1984).

oo Washington v Chrisman, 455 US 1, 15 (1981) (White dissenting).
} 
contributes to a leaner court system but eliminates the likelihood of exorbitant expert witness fees which would follow on the heels of a claim involving latent death. One might expect that as the span of time from injury to death increases, the testimony of those experts involved will necessarily become more lengthy and involved, costing the defendant (and the taxpayer, if the court must supply the expert) thousands of dollars. ${ }^{91}$

Yet efficiency should not trump the search for just results in homicide cases. ${ }^{92}$ Recall that the Supreme Court in Clarke decided on the rule because "in case of life, a rule of law ought to be certain." "93 The Court was thus concerned not with efficient procedure, but with the possibility of executing an innocent individual. It would therefore seem incongruous to assert efficiency as a justification for a rule that no longer reflects society's aptitude in determining causation with "certainty." The rule was designed as a safeguard against an unwarranted execution, not a budget deficit.

Furthermore, efficiency entails more than cost-effective procedures; it foresees accurate results. Professor LaFave, considering the propriety of adopting bright lines rules in the context of the Fourth Amendment, ${ }^{94}$ has proposed that a court ask several questions before adopting any such standards. LaFave suggests that one question should be: "Does [the bright line rule] produce results approximating those which would be obtained if accurate case-by-case application of the underlying principle were practicable?"'9s Stated hypothetically, LaFave's question allows departure from the confines of current resources by assuming for a moment that factfinding examinations in latent death cases would be "practicable," hence both plausible and economical. In the context of the year-and-a-day rule, one is left squarely with the question of whether the rule produces results consistent with those of a system employing forensic pathologists. It does not, therefore it must be abandoned.

"1 As of 1989, the typical physician charged $\$ 15-100$ per hour to prepare medical illustrations and between $\$ 40-125$ per hour to prepare courtroom exhibits. Physicians charged between $\$ 35-400$ per hour to prepare their testimony and between $\$ 100-500$ per hour to testify at trial. Comment, Contingent Expert Witness Fees: Access and Legitimacy, $64 \mathrm{~S}$ Cal L Rev 1363, 1364 (1991).

${ }^{92}$ Consider, in this regard, the common legislative provision for the automatic appeal of capital convictions.

${ }^{93} 152$ US at 239.

* Wayne R. LaFave, The Fourth Amendment in an Imperfect World: On Drawing "Bright Lines" and "Good Faith", 43 U Pitt L Rev 307 (1982).

${ }^{98}$ Id at $325-26$ (emphasis in original). 
Where the year-and-a-day rule was once thought to be the lesser of several evils, to contend that the rule approximates the results of modern forensic medicine is untenable and unjust. When the Supreme Court initially adopted the rule, there was no yardstick of accurate results by which the Court could judge the integrity of the rule. That the Court should have adopted an arbitrary standard therefore seems less offensive than the contention that it should retain the rule when the technology at hand can better serve justice. "Abandoning the judging of categories, courts should resume the judging of cases."

2. Peace of mind: the desire for determinate standards.

While the search for efficiency should be subordinated to the search for just outcomes in homicide cases, not all rationales behind the rule collide with the search for justice. Since this country was founded, legislatures have promulgated statutes of limitation in an effort not only to bar stale claims, but also to remove the air of uncertainty that would otherwise hover indefinitely over potential defendants. ${ }^{97}$ The year-and-a-day rule might be thought a similar measure, designed to mitigate a suspect's endless apprehension of conviction and death. ${ }^{88}$

The strongest rebuttal to this argument lies in the fact that those same legislatures that have chosen to define definite periods in which claims may be brought have considered the crime of murder unique. The United States Congress first made the distinction in 1790 , legislating that

no person or persons shall be prosecuted, tried or punished for treason or other capital offence aforesaid, wilful murder or forgery excepted, unless the indictment for the same shall be found by a grand jury within three years next after the treason or capital offence aforesaid shall be done or committed.99

\footnotetext{
90 Alschuler, $45 \mathrm{U}$ Pitt L Rev at 288 (cited in note 89).

${ }^{97}$ See Gary L. Milhollin, Interest Analysis and Conflicts Between Statutes of Limitation, 27 Hastings L J 1, 10 (1975) (finding that two basic policies underlie statutes of limitation: repose for defendants and judicial economy).

98 The use of the statute of limitations as an analogy seems particularly appealing in light of the genesis of the year-and-a-day rule as precisely such a statute. See Section I(A).

99 Acts of the First Congress, Statute II ch IX $\S 32,1$ Stat 119 (1790) (emphasis added).
} 
While subsequent versions of the statute have altered the list of excepted crimes, ${ }^{100}$ murder indictments continue to enjoy exemption from statutes of limitation. ${ }^{101}$

Given the considered legislative judgment that murder falls in a class unique among crimes, it follows that the year-and-a-day rule cannot rely on society's preference for determinate standards in order to survive. The same rationale that supports a murder indictment twenty years after the murder has been committed would support such an indictment in the event that the victim does not die until twenty years after the blow that sent her into a coma.

\section{A Compromise: The Rule as a Rebuttable Presumption}

The concerns expressed in Part B of this Section and the arguments in favor of the rule in Part $\mathrm{C}$ suggest that the rule should be modified if it is to have a place in modern homicide law. There are three reasons why the Supreme Court should not abolish the year-and-a-day rule but rather transform it into a rebuttable presumption. ${ }^{102}$

First, such an alteration of the rule would respect the state of modern medicine while maintaining a failsafe mechanism to guard against patently attenuated efforts at proving causation. To get to the jury, the prosecution would still bear the burden of overcoming the presumption that if the defendant died more than a year and a day after the precipitating harm, the defendant's actions were not the cause of death. The prosecutor would thus be forced to focus on that part of the case that will be most difficult to prove: whether or not the defendant's action (inflicting the virus, for example) was the hyper-immediate cause of the victim's death. This is clearly preferable to a world without the rule in which a prosecutor, able to prove that the defendant inflicted the harm, might bring an attenuated claim and hope that a sympathetic jury might convict solely upon evidence of the defendant's act and disregard the more ambiguous matter of whether the particular harm caused the death of the victim.

Second, what the "new" rule loses in efficiency is more than compensated for by what it gains: just results. While it will most

\footnotetext{
${ }^{100}$ See, for example, 18 USC $\S 581$ (1934) ("No person shall be prosecuted, tried, or punished for treason or other capital offense, willful murder excepted, unless the indictment is found within three years ....").

to1 18 USC $\S 3281$ (1988) ("An indictment for any offense punishable by death may be found at any time without limitation....").

${ }^{102}$ This suggestion also appears in Note, 65 Dickinson L Rev at 172 (cited in note 4).
} 
certainly be the case that this new version of the rule will allow for the classic (and expensive) battle of the experts in some cases, those cases will be those in which we want the parties to argue the issue of causation. If the prosecutor can meet her burden, then the case should go to the jury. This is consistent with the maxim expressed in Part $\mathrm{C}$ of this Section that the search for efficiency should be subordinated to the search for just outcomes in homicide cases.

Third, as a rebuttable presumption, the rule falls into place with the considered legislative judgment that murder is unique and should escape society's preference for determinate outcomes. The arbitrary limitation on the charge of murder once removed, the Government could seek an indictment for murder in the event a victim died ten years after the precipitating harm just as it might indict ten years after the victim suffered an instantaneous death.

\section{CONCLUSION}

One hundred years ago, the Supreme Court of this country adopted a rule that provided that no individual should be charged with murder if the victim of the alleged blow died more than a year and a day from the assault. No federal court has had the opportunity to reconsider, much less overrule, the doctrine since its initial acceptance. But judicially created rules have more to fear than explicit repeal.

As a rule of evidence, the year-and-a-day rule operates to bar the admission of relevant evidence in every case where a victim dies more than a year and a day after the injury. Such a rule is best understood as a conclusive presumption that is, practically speaking, a rule of substantive law. While one might argue that the rule should therefore appear in the federal murder statute, it seems clear that the framers of that statute understood that the rule would persist until expressly rejected. And while it might be tempting to argue that the Federal Rules of Evidence implicitly superseded the rule, it is precisely the substantive quality of the rule that dictates its survival.

Thus, the rule survives-an anachronism in the modern age. While once justified by the arcane state of medicine, there seems little place for a conclusive presumption that depends on an arbitrary time period in this age of modern forensic pathology. In light of the increasing concern over the AIDS epidemic, the ramifications of the rule's continued viability will become acutely apparent. Yet the competing concerns of efficiency, determinate standards, 
and justice suggest that the rule should not be abrogated, but rather transformed into a rebuttable presumption. 


\section{.}

